\title{
Impact of the pet trade on the Margarita capuchin monkey Cebus apella margaritae
}

\author{
Natalia Ceballos-Mago ${ }^{1, *}$, Carlos Enrique González ${ }^{2}$, David J. Chivers ${ }^{1}$ \\ ${ }^{1}$ Wildlife Research Group, The Anatomy School, University of Cambridge, Downing Street, Cambridge CB2 3DY, UK \\ ${ }^{2}$ Escuela de Geografía, Universidad Central de Venezuela, Ciudad Universitaria, Caracas, Venezuela
}

\begin{abstract}
The Critically Endangered Margarita capuchin monkey Cebus apella margaritae is a sub-species endemic to Isla de Margarita in the Venezuelan Caribbean Sea, and is the only wild primate on the island. The major threats affecting its survival are habitat fragmentation and poaching for pest control and the pet trade. As part of the Margarita Capuchin Project, a pioneering long-term project for the conservation of this monkey, we characterised the pet-primate population on a regional scale in the state of Nueva Esparta (Isla de Margarita, Isla de Coche and Isla de Cubagua) to generate recommendations for conservation decision making. We conducted a survey of pet primates in the region, made an assessment of intestinal parasites in pet primates, and interviewed hunters. Information about species, current location, sources and trade routes were gathered. We found 162 pet primates representing 5 species; of this total, 35 were Margarita capuchins. We also found that at least 100 Margarita capuchins have been hunted for the pet trade in the last $25 \mathrm{yr}_{\text {; }}$ this is cause for considerable concern in terms of the conservation of a wild population of less than 300 individuals. Illegal pet-trade on both a national and an international level was revealed in this study. We detected pet primates infected with intestinal parasites common to humans and domestic animals (Strongyloides stercolaris, Ancylostomas sp., Toxocara leonine and Blastocystis hominis), and using GIS analysis, we identified areas of potential high threat of disease transmission and hybridisation if escaped pet primates were to reach the Margarita capuchin habitat. Preventing the illegal trade of all monkey species, law enforcement and the establishment of a Monkey Rescue Centre to conduct a management programme for the existing Margarita capuchin pet population are among the conservation actions urgently needed in this region.
\end{abstract}

KEY WORDS: Margarita capuchin - Isla de Margarita · Pet trade - Cebus apella margaritae • Hybridisation · Disease transmission · Parasites · Isla de Coche

\section{INTRODUCTION}

The Margarita capuchin Cebus apella margaritae, a sub-species endemic to Isla de Margarita in the Venezuelan Caribbean Sea, is the only wild primate on this island. It is listed as Critically Endangered, considered one of the most threatened primates within the country and is included in Appendix II of the Convention on International Trade in Endangered Species of Wild Fauna and Flora (CITES). Estimates for the total population are less than 300 individuals, which are confined to remnant forest fragments in the east of the island. A $25 \%$ decline of the total population is expected over the next 15 yr (Bodini \& Perez-Hernández 1987, Sanz \& Marquez 1994, Rodríguez \& RojasSuárez 1999, 2008, Ceballos 2008).

Part of the Margarita capuchin distribution is within protected areas; nevertheless, it is still threatened by a reduced and fragmented habitat and by poaching. Although there are no reports of primate consumption on the island, poaching occurs for pest control and for the pet trade (Sanz \& Marquez 1994, Ceballos 2008, Rodríguez \& Rojas-Suárez 2008). Previous data on the Margarita capuchin pet trade come from preliminary 
surveys on Isla de Margarita (Ottocento et al. 1989, Marquez \& Sanz 1991, Martínez et al. 2000, CeballosMago 2005). Hunting of monkeys is illegal in Venezuela, and legislation regulates any capture of or trade in wildlife (Ley de protección a la fauna silvestre 1970, Ley penal del ambiente 1992, Ley de gestión de la diversidad biológica 2008). Nevertheless, there are legal gaps about keeping wildlife as pets, and there is lack of evaluation of the pet trade both at the regional and the national level (Mujica et al. 2003).

Introduction of any pet primate into the free-living Margarita capuchin habitat generates additional concern about disease transmission, hybridisation and resource competition (Chivers 1991, Martínez et al. 2000, Baker 2002, Fragaszy et al. 2004). The latter is not currently the main threat, since only a few individuals of another species were detected in the Margarita capuchin distribution range after intensive and systematic surveys (N. Ceballos-Mago unpubl. data), but any single pet primate released or escaped that reaches Margarita capuchin habitat could be considered a threat for the wild population due to potential disease transmission and hybridisation.

Since some diseases, such as intestinal parasites, can be transmitted through intermediate hosts, once an infected pet primate reaches the habitat of the wild monkeys, this already represents a potential threat. A primate population already endangered by habitat loss, habitat fragmentation and hunting is also threatened by a significant risk of parasitic infections, which can cause short-term reduction in population size (Chapman \& Peres 2001, Chapman et al. 2005).
Causes for concern over hybridisation exist due to the confirmed trade of wedge-capped capuchins Cebus olivaceus to Isla de Margarita (Martínez et al. 2000, Ceballos-Mago 2005). The Margarita capuchin and the wedge-capped capuchin belong to the welldifferentiated 'tufted' and 'untufted' groups, respectively (Rylands et al. 2005) (Fig. 1). Nevertheless, hybrid capuchins between these differentiated groups have been observed in captivity as well as in the wild (The Monkey Sanctuary: www.monkeysanctuary.org/ educationzone/capuchin.aspx, Kierulff et al. 2005, Rylands \& Mittermeier 2009, R. Martínez pers. comm.).

The few initiatives for researching the pet trade in the Neotropics point to the need for more systematic and intensive surveys to understand the extent of the threat for wildlife populations and to find creative and effective conservation actions (Chapman \& Peres 2001, Duplaix 2001, Duarte-Quiroga \& Estrada 2003, Kierulff et al. 2005, Altherr 2007, Estrada 2009).

As part of the Margarita Capuchin Project, a pioneer long-term project on the ecology and conservation of the Margarita capuchin, we characterised the population of pet primates on a regional scale in the state of Nueva Esparta, Venezuela (Isla de Margarita, Isla de Coche and Isla de Cubagua). We conducted a pet survey, hunter interviews and an intestinal parasite assessment, together with a Geographic Information System (GIS) analysis to determine areas of potential threat for disease transmission and hybridisation, if escaped pet primates reach the Margarita capuchin habitat. This regional characterisation allowed us to determine the impact of the pet trade on the Margarita
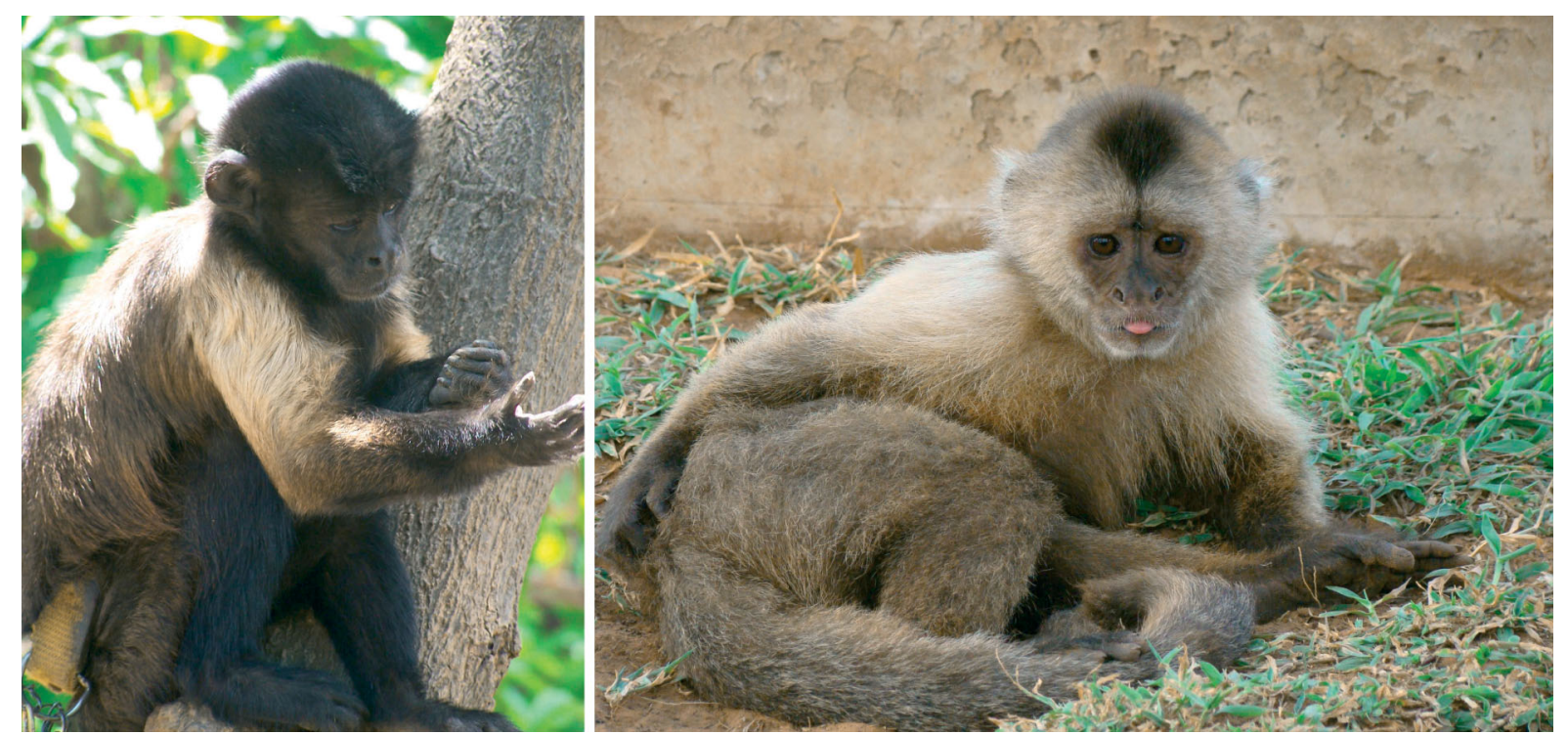

Fig. 1. Margarita capuchins Cebus apella margaritae (left) and wedge-capped capuchins Cebus olivaceus (right) belong to the well-differentiated 'tufted' and 'untufted' groups. Nevertheless, hybrid capuchins between these groups have been observed (Photos: N. Ceballos-Mago [left] and FUNDANISIL [right]) 
capuchin's wild population, and to generate recommendations for conservation decision making.

\section{MATERIALS AND METHODS}

Study area. The wild population of Margarita capuchins is located only on Isla de Margarita, but, to consider the regional scale of the pet trade, this study was conducted in the whole state of Nueva Esparta in the Venezuelan Caribbean Sea. This state comprises 3 islands: Isla de Margarita (1071 km²; 400000 inhabitants), Isla de Coche (55 km²; 12000 inhabitants) and Isla de Cubagua ( $24 \mathrm{~km}^{2} ; 50$ inhabitants) (Fig. 2). Nueva Esparta is one of the most important tourist destinations for Venezuelans, and it is also visited by foreigners, mainly Europeans (CORPORTUR 2009). Although Isla de Margarita receives most of the visitors, the tourist business on Isla de Coche has also been growing recently, while Isla de Cubagua does not have any tourist infrastructure. Isla de Margarita comprises the eastern sector $\left(741 \mathrm{~km}^{2}\right)$ and the western sector (Península de Macanao, $330 \mathrm{~km}^{2}$ ), linked by an isthmus (Sanz 2007). Tourist development is focused in the eastern sector, while the Península de Macanao is inhabited mainly by fishermen.

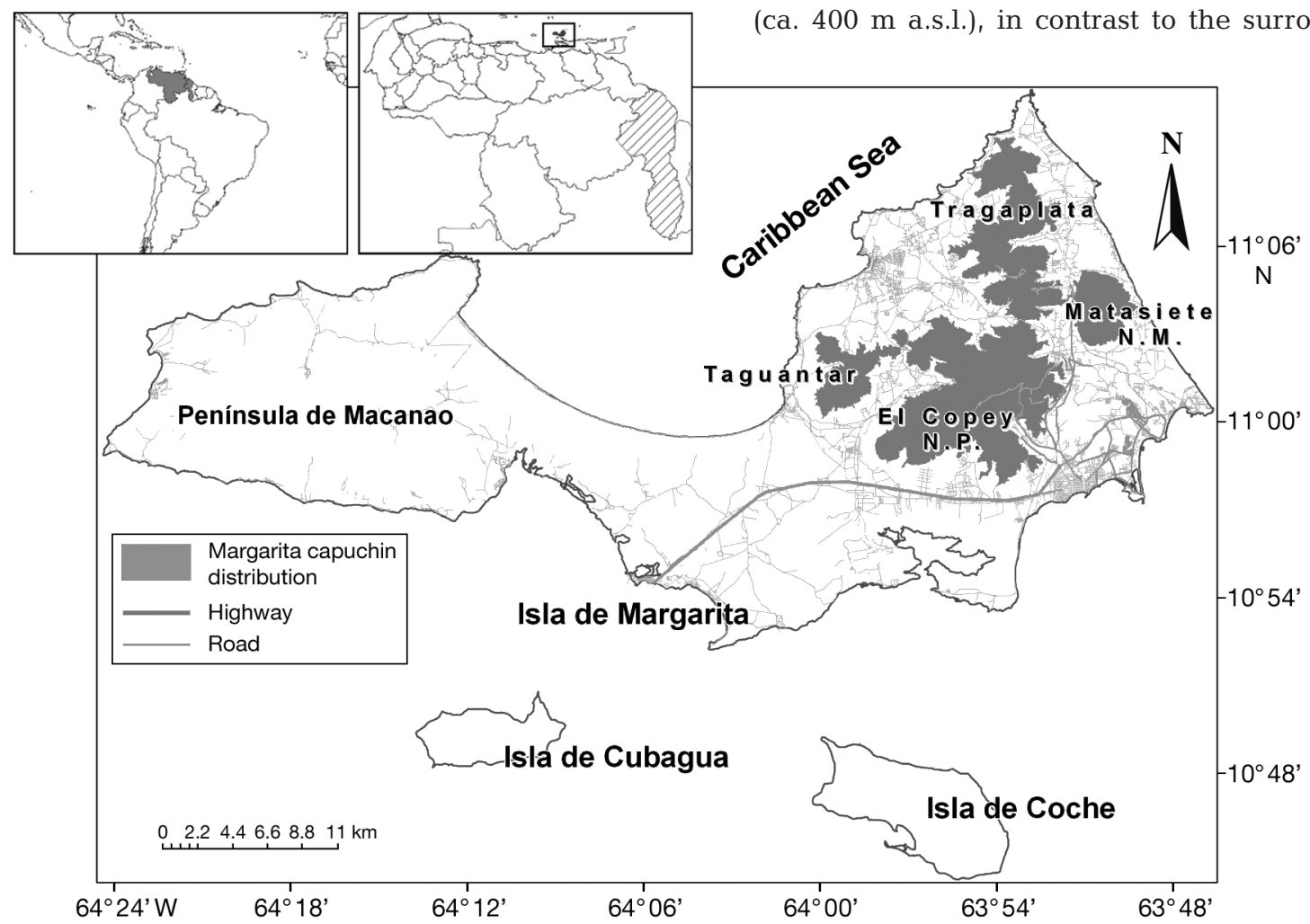

Fig. 2. Study area in Venezuela: Isla de Margarita, Isla de Coche and Isla de Cubagua (state of Esparta). The distribution of Margarita capuchins comprises 4 mountain forest fragments: Cerro El Copey National Park, Cerro Matasiete, which is part of Cerros Matasiete y Guayamurí Natural Monument, Tragaplata range and Cerro Taguantar. Valley with towns, agricultural areas and roads separate these mountain forest fragments
Isla de Margarita is not only the habitat of the Margarita capuchin, but is also one of the most diverse islands in the Caribbean, considering the number of species and ecosystems harboured (Sanz 2007). The island is part of the Caribbean biodiversity hotspot, and at least 7 of its 18 endemic terrestrial vertebrates are Endangered (Myers et al. 2000, Rodríguez 2007). Human encroachment for settlements and agricultural practices are the main causes of forest fragmentation on Isla de Margarita. Protected areas on the island are becoming increasingly isolated within this human-dominated landscape matrix. Valleys with towns, agricultural areas and roads separate these remnants (Fig. 2).

Cerro El Copey National Park (El Copey NP, 7130 ha, 930 m a.s.l., IUCN II; see Dudley 2008 for IUCN categories description), Cerro Matasiete (Matasiete NM, 1145 ha, $660 \mathrm{~m}$ a.s.l.), which is part of Cerros Matasiete y Guayamurí Natural Monument (IUCN III), and the unprotected areas of the Tragaplata range (Tragaplata, 4000 ha, $680 \mathrm{~m}$ a.s.l.) and Cerro Taguantar (Taguantar, 1300 ha, $500 \mathrm{~m}$ a.s.l.) are the 4 mountain forest fragments available to the Margarita capuchin (Marquez and Sanz 1991, Ceballos-Mago in press) (Fig. 2). El Copey NP, Matasiete NM and Tragaplata are of particular ecological interest, given the presence of cloud-forest pockets at exceptionally low altitudes (ca. $400 \mathrm{~m}$ a.s.l.), in contrast to the surrounding arid 
lowlands (Sugden 1986, Xena de Enrech et al. 1998). Taguantar, on the other hand, is entirely covered by dry vegetation.

Data collection. A pet survey and faecal sample collection were conducted across Isla de Margarita, Isla de Coche and Isla de Cubagua. Hunter interviews were conducted only on Isla de Margarita. This island was surveyed from March 2005 to April 2008, while $1 \mathrm{~d}$ visits to Isla de Coche and Isla de Cubagua each were sufficient to conduct the pet survey. All interviews for the pet and hunter surveys (see below) were conducted by the first author, accompanied on some occasions by assistants.

Pet survey: A semi-structured interview, following the ethnographic approach, was used to gather the information (Duarte-Quiroga \& Estrada 2003). We surveyed $70 \%$ of the towns in the study area, following the National Institute of Statistics (INE 2001) definition of towns. People possessing pet primates were located by word of mouth. When visiting a town with no previous information about pet primates, the first place that we approached in looking for information was a central shop. Information about pet primates was also formally and repeatedly requested from the regional office of the Ministry of Environment with no success. Any primate species found on the islands was included in the pet survey.

Dead primates were only included in the survey if they had died in 2004 (a year before the survey started) or later, and only if pictures or a good description of the animal allowed the interviewer to identify the species. Pairs of different capuchin species living together and atypical colour patterns of individuals living on the islands were recorded to evaluate hybridisation.

The following data were collected in every interview: (1) primate species (identified by the interviewer); (2) location (location of the pet using GPS when possible or by location of the town on a map); (3) trade (origin, cost and trade route).

Faecal test for intestinal parasites: When possible, fresh faecal samples were collected from pet primates and checked by a local veterinarian for parasitic infection, using direct faecal examination and by flotation in a saturated saline solution.

Hunter interviews: Hunters were located by word of mouth. Any person we found that had hunted at least 1 monkey was considered to be a hunter. Hunting grounds and techniques, numbers of monkeys hunted, motivations and selling prices were assessed. 'Hunting' was considered as all captures of wild animals by humans, whether dead or alive and irrespective of the techniques used to capture them (Robinson \& Bennett 2000).

Data analysis. Pet survey and hunter interviews: Data from the pet survey and hunter interviews were entered in a database. Open-ended questions were codified to facilitate analysis. Selling prices were converted to US\$ at the appropriate exchange rate for the time when the data were collected; they were then converted to the value corresponding to 2008. Descriptive statistics for the data collected were conducted.

Pet trade: a potential threat for the wild Margarita capuchin population (GIS analysis): A GIS database was developed for the study area using ARCGIS 9.1, including data regarding current monkey locations. Since pet primates easily break ropes and open cages, especially capuchins that are recognised for their cleverness in escaping (Fragaszy et al. 2004), GIS analysis was carried out to determine the probability of each pet reaching the mountains, in case of escape. This was a preliminary and exploratory analysis conducted to determine the geographic areas that represent a higher threat of disease transmission and hybridisation for the wild population, in terms of pet primate location, species, density and access to the Margarita capuchin habitat.

Access index: 3 GIS data layers were used to generate an access index: (1) Roads 1:25000 (IGVSB 1997); (2) Hydrology 1:25000 (IGVSB 1997); and (3) Isla de Margarita vegetation map 1:100000 (González 1999). These layers were re-classified on a scale from 1 (lowest) to 5 (highest), according to the level of difficulty of movement for monkeys through that cover. They were then converted to a raster format to conduct the map algebra technique. The 3 layers were added together, obtaining values from 1 to 15 , with 15 representing the highest difficulty of movement for primates.

Threat map: using the access index, an access value for each primate was calculated, adding the pixels found in a straight line from the pet primate location to the nearest Margarita capuchin distribution borderline. A constant value of 0 (highest threat) was assigned to pet monkeys living inside Margarita capuchin habitat and 1000 (lowest threat) to monkeys located more than $13 \mathrm{~km}$ from the Margarita capuchin distribution. For cartographic purposes, these values were inverted to be represented as lowest threat (0) and highest threat (1000). For wedge-capped capuchins, a constant arbitrary value (500) was added to consider the extra threat that this species represents for hybridisation. We did not add an extra value for the brown capuchin found, because this was located in the western Isla de Margarita (Península de Macanao; Fig. 3), far from the distribution of the wild population. Values from 0 to 1497 were obtained; pets with scores of 1497 represented the highest potential threat for the wild population. Kernel density $\left(1500 \mathrm{~m}^{2}\right.$ pixel size and $3 \mathrm{~km}$ radius) was used to produce threats for the entire Isla de Margarita. The threat values were re-scaled from 1 to 5 , using a bilinear interpolation. 


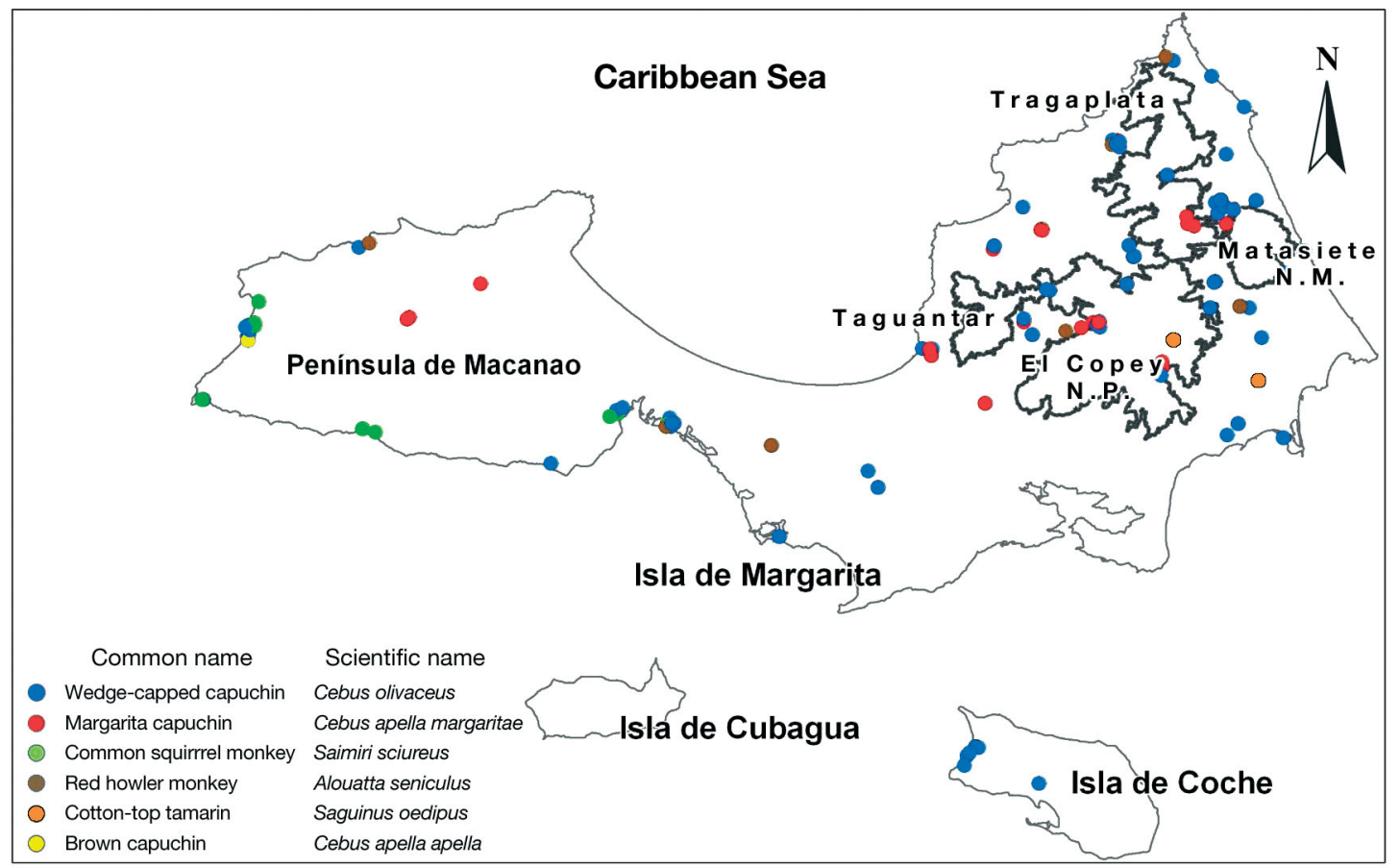

Fig. 3. Distribution of pet primates in the state of Nueva Esparta (comprising Isla de Margarita, Isla de Coche and Isla de Cubagua)

\section{RESULTS}

We found 162 pet primates. Most of them were on Isla de Margarita $(95 \%, \mathrm{n}=154)$, and the other $5 \%(\mathrm{n}=$ 8) were on Isla de Coche. Isla de Cubagua had no pet primates (Fig. 3). Five different pet-monkey species were found. The wedge-capped capuchin was the most common $(64 \%, \mathrm{n}=104)$, followed by the Margarita capuchin $(21 \%, \mathrm{n}=35$; Fig. 4). The majority of pet primates were living in houses $(69 \%, n=111)$, while $23 \%(n=38)$ were exhibited as tourist attractions in restaurants or other commercial establishments, and $8 \%(\mathrm{n}=13)$ were in a Rescue Centre (FUNDANISIL).

\section{Sources for the pet trade}

The highest percentage of pet monkeys came from the Venezuelan mainland $(67 \%, \mathrm{n}=109)$, while $22 \%$ ( $n=36$ ) were captured across the Margarita mountains (35 were Margarita capuchins and the other was identified as a wedge-capped capuchin), and 10\% (n = 17) came from other countries.

\section{Trade in Margarita capuchins}

Pet Margarita capuchins were found only on Isla de Margarita and were captured from every forest frag- ment within the species distribution. Details about the sources of pet primates were reported for 31 of the 35 Margarita capuchins found: $48 \%(\mathrm{n}=15)$ were extracted from El Copey NP, $29 \%(n=9)$ from Taguantar, $13 \%(n=4)$ from Matasiete NM and 10\% $(n=3)$ from Tragaplata.

According to hunter interviews ( $\mathrm{N}=31$ interviews), of 166 Margarita capuchins hunted between 1975 and 2007, $72(43 \%)$ were captured to be sold, $29(18 \%)$ to keep as pets, $63(38 \%)$ were hunted for pest control and $2(1 \%)$ were hunted to sell the tails for medical purposes. Most capture events were carried out within the last 25 yr (99\%), and most Margarita capuchins captured for the pet trade came from Taguantar $(66 \%$, $\mathrm{n}=67$ ), $13 \%$ came from Matasiete NM, $11 \%$ from El Copey NP and $10 \%$ from Tragaplata.

Hunters were very imprecise about the technique used to capture the monkeys; only 1 hunter said that he killed the mother to get the infant, 1 used a cage and 3 used stones and lemons to hit the mother. Others said that the mother 'left' the infant. Since most of the pets were received very young (N. Ceballos-Mago \& D. Chivers unpubl.), it is highly probable that the mother was killed or severely hurt in most cases.

Hunters on Isla de Margarita considered selling the capuchins for a good 'extra income'. The average price of Margarita capuchins according to hunters was US\$ $289.30 \pm 22.30$ (range 46-451). Information about Margarita capuchins being exported was difficult to find. 


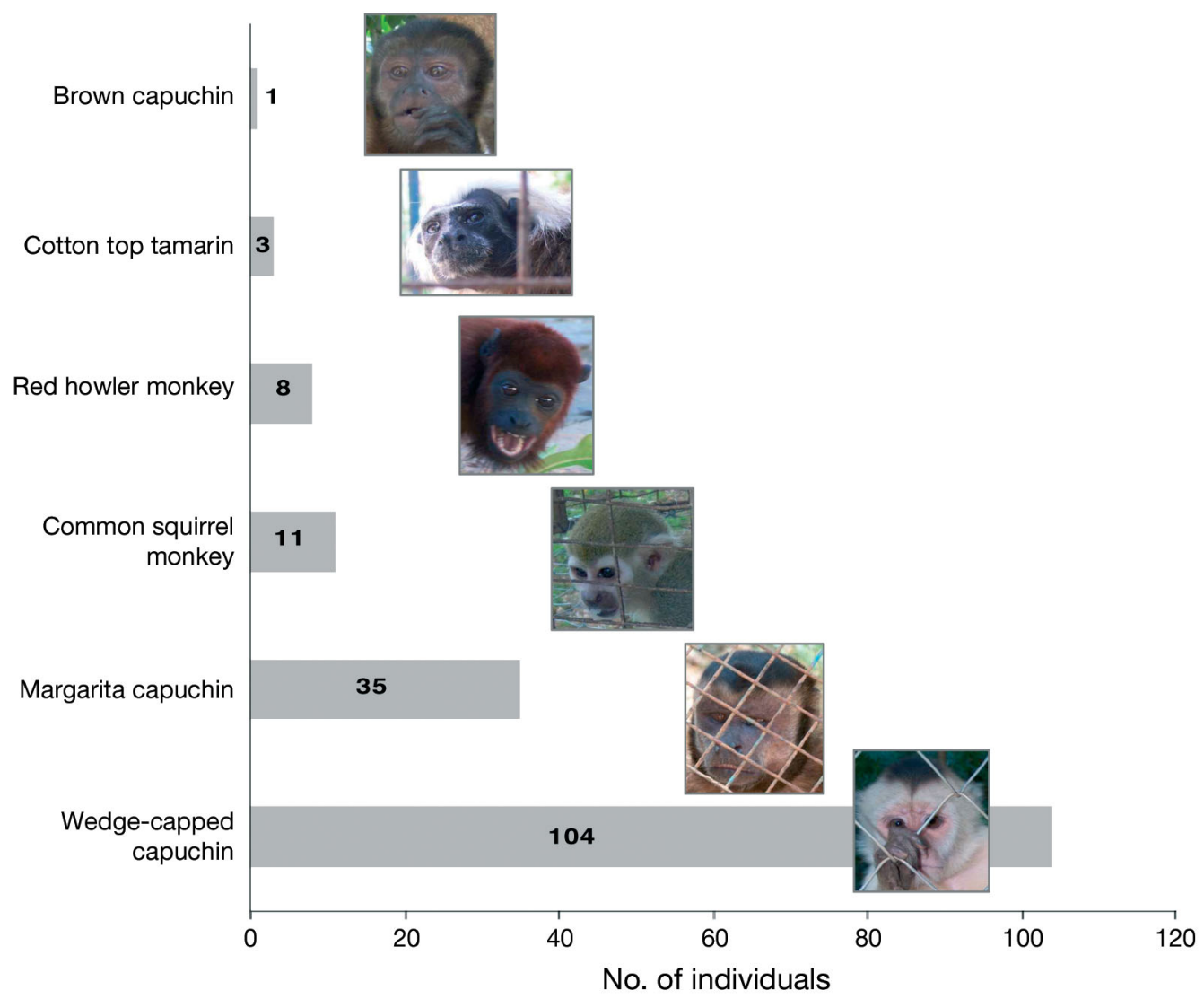

Fig. 4. Number of ind. of each pet-primate species (see Fig. 3 for scientific names) in Nueva Esparta. Photos: N. Ceballos-Mago

According to additional records, we found that 1 Margarita capuchin was taken to Colombia and 9 were sold to international tourists through a hotel contact.

\section{Trade in other pet primates}

Information about sources of pet monkeys from the Venezuelan mainland was found for 43 monkeys. Anzoategui $(35 \%, \mathrm{n}=15)$, Delta Amacuro (16\%, $\mathrm{n}=7$ ) and Sucre $(14 \%, n=6)$ were the main states mentioned as origins (Fig. 5).

The Guayana Shield Eco-region (Guyana, Surinam and French Guiana) was the main source of monkeys that came from other countries (Fig. 6). All common squirrel monkeys and the brown capuchin were located in the Península de Macanao (Fig. 3) and came from this Eco-region. Fishermen that live on this peninsula travel to the Guayana Shield and bring the primates to keep them as pets in their houses or to sell them to neighbours. Two cotton-top tamarins were brought from Colombia and 1 from Panama.

Private boats, fishing boats, ferries and airplanes were reported as means of transport for pet monkeys into the islands. Isla de Margarita was used as the intermediate point in the trade route to Isla de Coche for 2 of the pet monkeys. All monkeys on Isla de Coche were wedge-capped capuchins.

Of 50 monkeys surveyed in detail (N. Ceballos-Mago \& D. Chivers unpubl.), 22 (44\%) were bought at an average price of US\$ $169.30 \pm 59.60$ (range 31-1126). From anecdotal evidence, we found that traders traffic wedge-capped capuchins from the Venezuela mainland to Isla de Margarita. In total, 5 traders were identified in this study.

During the pet survey, we found no atypical colour patterns of individuals, nor any sign of possible hybrids living in captivity. Nevertheless, Margarita capuchins and wedge-capped capuchins were found living in the same house in 5 of those surveyed. In all cases, people did not know they were different species. In 2 cases they put them together intentionally to get the female pregnant. In 1 case, a male was 'borrowed' from another house for this purpose. Pregnancy did not occur during the survey time, and the respondents were told about the differences between these species and the problems that such inter-breeding could cause. They were asked to separate the monkeys. At least 5 wedge-capped capuchins were released in forest fragments by local people during the survey time, 


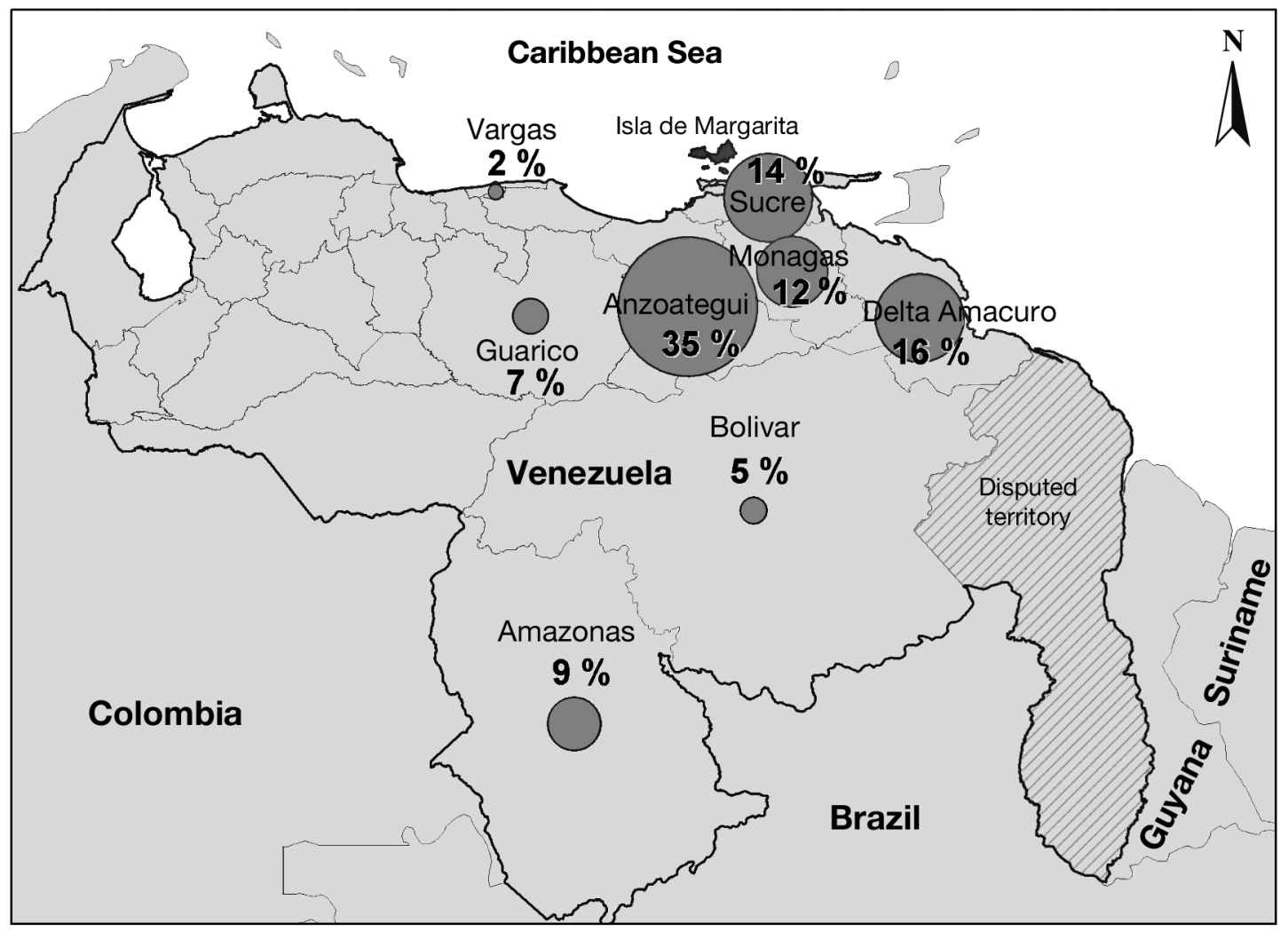

Fig. 5. Sources of pet monkeys surveyed in Nueva Esparta $(n=43)$, showing the states of origin on the Venezuelan mainland

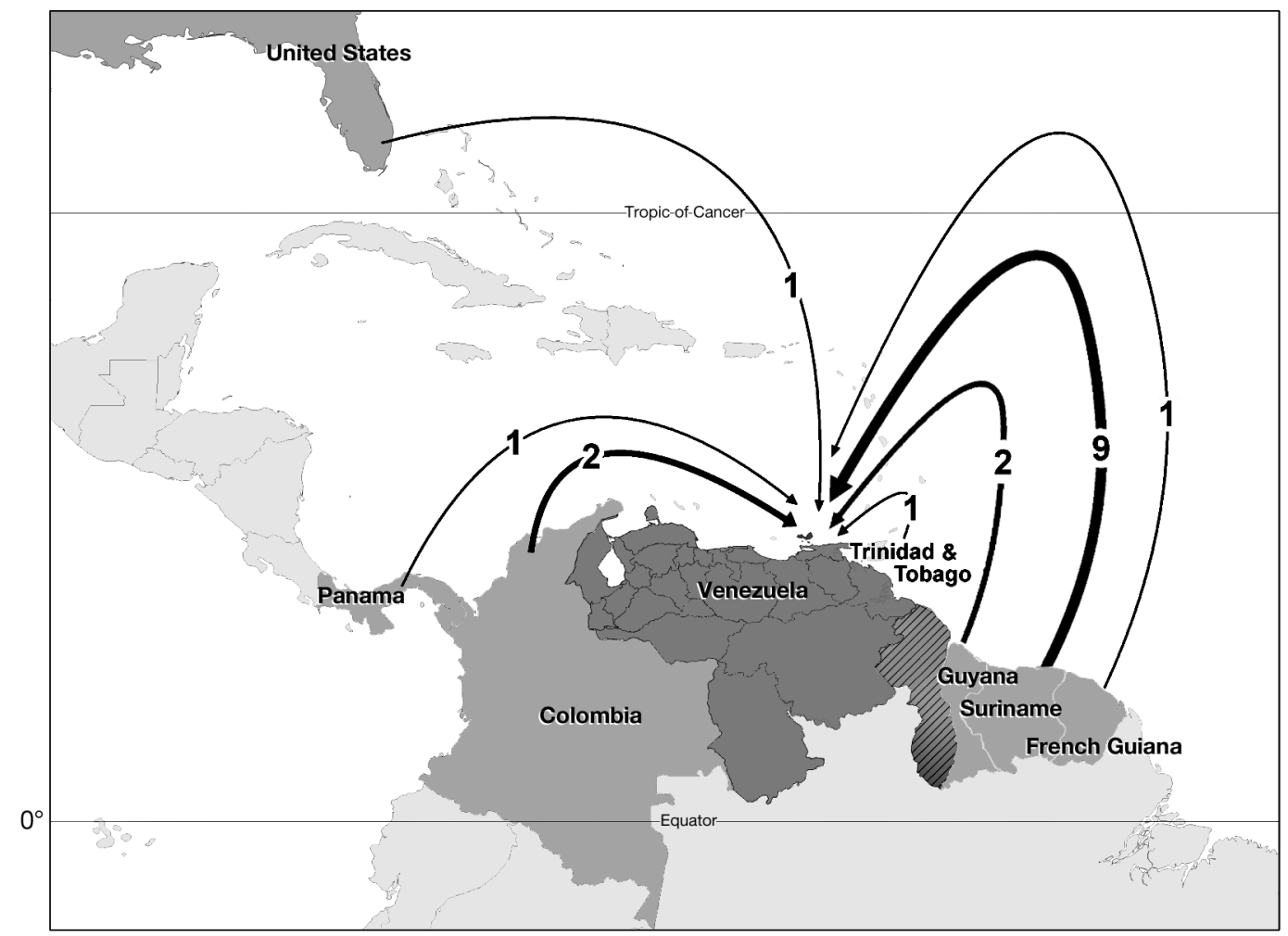

Fig. 6. International trade routes for pet monkeys from other countries to Nueva Esparta, Venezuela. Numbers on lines indicate the numbers of monkeys traded; thicker lines reflect greater numbers traded 
and 1 pet primate identified as a wedge-capped capuchin in the pet survey was captured by a hunter in Tragaplata.

\section{Intestinal parasite infection in the pet population}

Among 31 faecal samples taken (16 from Cebus apella margaritae and 15 from C. olivaceus), parasites were detected in $16 \%(n=5)$ of the pet monkeys, 4 of which were Margarita capuchins and 1 wedge-capped capuchin. All infected monkeys were located on Isla de Margarita. The parasites found were the nematodes Toxocara leonine, Strongyloides stercolaris, Strongyloides sp. and Ancylostomas sp. and the protozoan Blastocystis hominis (1 species ind. ${ }^{-1}$ ). Two animals showed symptoms such as hair and weight loss and lethargic behaviour, while the other 3 did not show any symptoms of infection (Table 1).

\section{Pet trade: a potential threat for the wild Margarita capuchin population}

Most pet monkeys were located in the east side of Isla de Margarita ( $81 \%, \mathrm{n}=131)$, close to the wild Margarita capuchin distribution (see Figs. 2 \& 3). From a sample of 50 pet primates, where more detailed information was gathered (N. Ceballos-Mago \& D. Chivers unpubl.), 42 monkeys (84\%) escaped captivity several times. Despite most of them being recaptured, 5\% $(\mathrm{n}=$ 8) remained free.

Through the exploratory GIS analysis, areas that represent a potential high threat for the wild Margarita capuchin population were found surrounding the 4 mountain forest fragments (Fig. 7). Pet monkeys located on the eastern side of the island represent the 2 highest threats for the wild capuchin population, especially in Matasiete NM, Tragaplata and El Copey NP. Pets located between Tragaplata

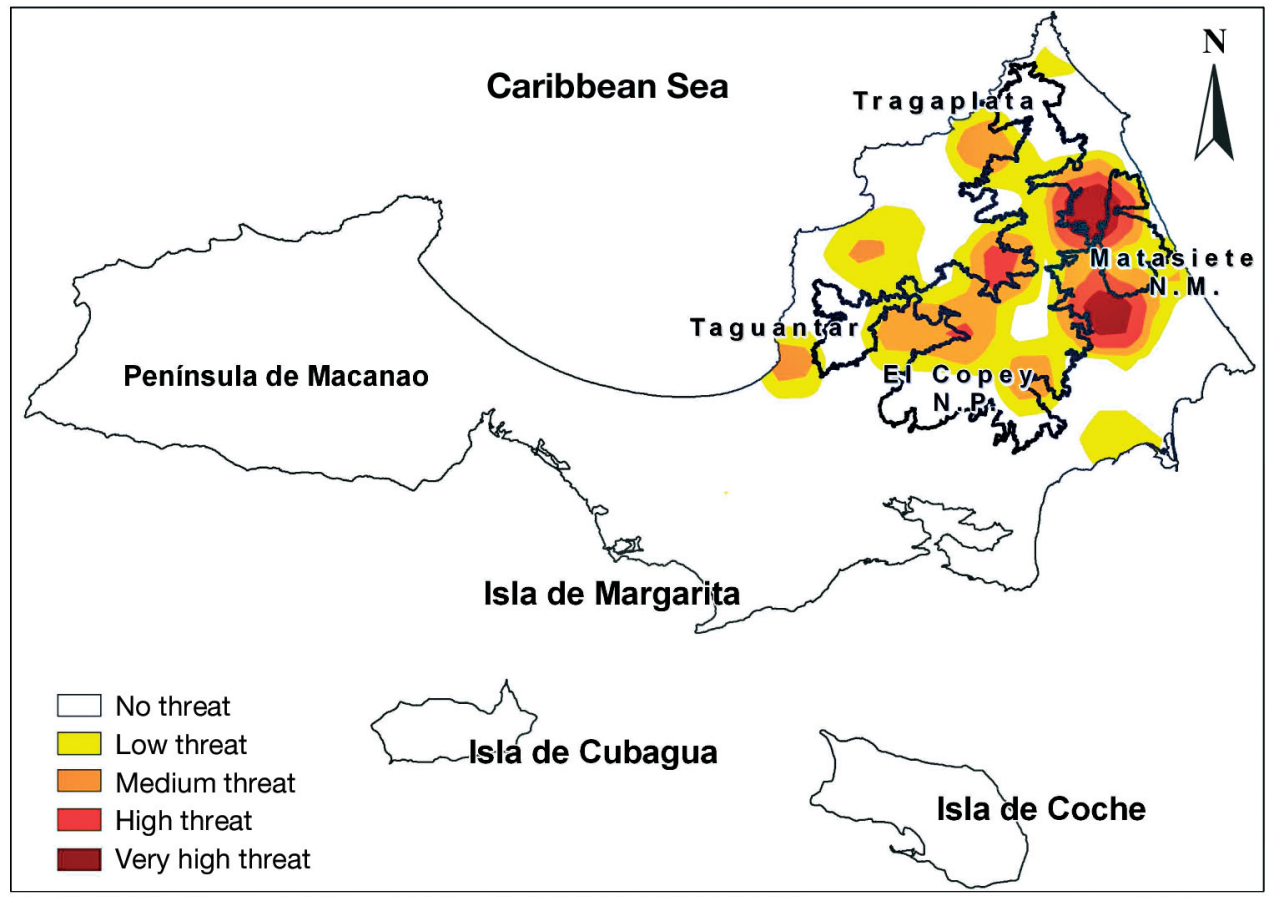

Fig. 7. Threat gradient for wild Margarita capuchins. Red areas represent a potentially very high threat in terms of pet primate location and probabilities of reaching the Margarita capuchin habitat, together with pet population density and species involved

Table 1. Parasitic infections in pet primates in the study area

\begin{tabular}{|llcl|}
\hline Parasite & \multicolumn{1}{c}{ Primate species } & Sex & \multicolumn{1}{c}{ Symptom } \\
\hline Toxocara leonine (eggs) & Cebus apella margaritae & $\mathrm{M}$ & No symptoms \\
Strongyloides sp. (larvae) & Cebus apella margaritae & $\mathrm{M}$ & No symptoms \\
Strongyloides stercolaris (larvae) & Cebus apella margaritae & $\mathrm{M}$ & Hair and weight loss, lethargic behaviour \\
Ancylostomas sp. (eggs) & Cebus apella margaritae & $\mathrm{F}$ & Hair and weight loss, anaemia \\
Blastocystis hominis & Cebus olivaceus & $\mathrm{F}$ & No symptoms \\
\hline
\end{tabular}


and El Copey NP, to the west of these 2 forest fragments, are also a potential threat, but at a lower level. Taguantar is surrounded by 3 areas of medium threat.

\section{DISCUSSION}

\section{Margarita capuchin trade}

Margarita capuchins are being increasingly hunted for the pet trade, in comparison to previous records by Ottocento et al. (1989), Marquez \& Sanz (1991) and Martínez et al. (2000). The figures we found (35 Margarita capuchins as pets and at least 100 hunted for the pet trade in the last $25 \mathrm{yr}$ ), added to an unknown number of females seriously injured or killed to capture the infants, generate great concern for a fragmented population of less than 300 individuals. The collateral mortality of other monkeys while trying to capture a baby or juvenile increases the impact of hunting on wild populations (Ohl-Schacherer et al. 2007, de Thoisy et al. 2009, Nijman 2005a).

Hunting for the pet trade disrupts the age and sex structure of the population. Removal of individuals from their social groups has a disproportionate impact on the population as a whole. Their slow reproduction rates, including relatively long birth intervals, the birth of single infants, limited reproductive capacity of some females due to complex group structures, slow maturation and lengthy parental dependency, are the main biological characteristics that make the Margarita capuchin populations, like other primates and animal species with similar characteristics, particularly susceptible to over-exploitation (Nijman 2005a,b, Redmond 2005, Altherr 2007).

There are also behavioural changes, such as cryptic behaviour and less active foraging due to the disturbance caused by hunters, which may affect patterns of group dispersal and contribute to population declines in primates (Johns \& Skorupa 1987, de Thoisy et al. 2009). Margarita capuchins are particularly shy and cryptic, avoiding human contact probably due to hunting pressure (Marquez \& Sanz 1991, Ceballos-Mago in press). Although this behaviour is far from the one generally described for Cebus spp., which are considered to be intimidating, active and noisy monkeys, it is displayed when predation risk is high and has also been reported for other species subject to high hunting pressure (Bshary 2001, Fragaszy et al. 2004, Moura 2007. G. Canale pers. comm.).

Hunting for pest control has decreased to some extent, but this still persists, adding pressure to the Margarita capuchin population (Moncada 2007). Species inhabiting fragmented areas, such as the Mar- garita capuchin, are more vulnerable to hunting than species living in areas of continuous forest cover, due to lack of continuous immigration and easy access of hunters to the fragments (Glanz 1991, Robinson 1996, Turner \& Corlett 1996). On Isla de Margarita, park rangers patrol the protected forest fragments, but they cannot cover the whole protected area and there are still not enough rangers to patrol every day. The human population living near the border of El Copey NP has very easy access. Local people normally go to this NP for agricultural activities and recreation, but also to hunt when it is not patrolled. Taguantar, the forest fragment where more monkeys were extracted according to hunters, is currently unprotected, has no patrols, and hunting pressure not only for monkeys, but also other endemic sub-species, such as the Margarita deer and rabbit, is very high. Although local people had seen Margarita capuchins living in Taguantar at least $50 \mathrm{yr}$ ago, their presence in this fragment was formally determined only recently (Ceballos-Mago in press).

\section{Other primate species traded on the islands}

Primate trade occurs locally, nationally and internationally. The state of Anzoátegui, the main origin of pet monkeys, is a hotspot for wildlife trade in Venezuela. The wedge-capped capuchin, the most common pet primate on the island, is the most widely distributed and preferred pet primate in Venezuela (Cordero Rodríguez \& Boher 1988, Urbani 2006). This species is listed as one of the species most threatened by illegal trade in the country (Mujica et al. 2003).

The location of Isla de Margarita and Isla de Coche, their situation as a tourist destination and lack of legal control make these islands easy destinations for the pet trade. Primates have been brought from the USA, Trinidad, Panama, Colombia and the Guayana Shield Eco-region. The latter, unique due to its biodiversity and largely uninhabited rainforest, is the main source of monkeys that arrive to Nueva Esparta from outside Venezuelan borders. Although the common squirrel monkey and the brown capuchin inhabit the south of Venezuela, all surveyed pets of these species came from the Guayana Shield Eco-region. Despite the reduced trade of brown capuchins Cebus apella apella found in this study, this is a potential threat to Margarita capuchins given the phenotypic similarities between the 2 sub-species. Trips by fishermen from Nueva Esparta to this region make this a frequent, uncontrolled and reciprocal trading route, not only for primates, but also for other wildlife species. Duplaix (2001) and Altherr (2007) highlighted the need for closer monitoring of the wildlife trade in this region. 


\section{Pet trade: a potential threat for the wild Margarita capuchin population}

The wild population of Margarita capuchins is under a potential threat of disease transmission and hybridisation in the 4 forest fragments that constitute the species distribution. El Copey NP, Tragaplata and Matasiete NM are surrounded by areas of highest threat. The abundance of pet primates living in Margarita capuchin habitat is likely low according to intensive and systematic surveys (N. Ceballos-Mago unpubl. data); nevertheless, a wedge-capped capuchin was observed in a group of Margarita capuchins in El Copey NP, we confirmed the release of at least 5 wedge-capped capuchins during the pet survey, and calls of howler monkeys were also heard in Matasiete NM (N. Ceballos-Mago unpubl. data).

\section{Disease transmission}

Released pet primates, free-ranging domestic animals and humans can carry parasites into wild populations. Through the faecal samples tested, we found evidence of parasitic infections in pet primates that could be transmitted to the wild Margarita capuchin population. Parasitic infection by the nematode Strongyloides is common in many primates (Corning 2005). Nevertheless, this parasite and the others found in this study are not specific to monkeys; they could have been transmitted by domestic animals or humans. Little information is available concerning intestinal parasites in Neotropical primates, especially for wild Cebus, Callicebus and Saguinus (Phillips et al. 2004, Colosio 2009).

Prevention of emerging zoonoses and anthropozoonoses is presently a challenge, when the dynamics of human and non-human primate interactions are changing radically (Chapman et al. 2005, Corning 2005). Transmission of gastro-intestinal parasites is affected by the degree and nature of anthropogenic disturbance of forest fragments, and they can affect host health condition, reproduction and even host survival (Scott 1988, Dobson \& Hudson 1992, Coop \& Holmes 1996, Chapman \& Peres 2001). There is need for research, both in pristine and fragmented habitats, given the critical importance of parasites for conservation and management of endangered species (May 1988, Thorne \& Williams 1988, Chapman et al. 2005, Gillespie \& Chapman 2006, Chomel et al. 2007, Trejo-Macías et al. 2007).

\section{Hybridisation}

Hybridisation could be a potential and complex problem for the long-term survival of Margarita capuchins, given the abundance of wedge-capped capuchins as pets across the island, their reported release and their ability to escape from captivity. Although hybridisation is not currently the main threat for the wild population, any management plan focused on the conservation of the Margarita capuchin needs to consider this threat and minimise its impact. This process can lead species to extinction, and conditions such as habitat fragmentation and destruction only aggravate the situation (Rhymer \& Simberloff 1996, Allendorf et al. 2001). The current presence of hybrids in the population can be investigated through genetic analyses. Current conditions of isolation for this sub-species, which lives not only on an island, but also in a fragmented habitat, open the opportunity to study its taxonomic status and origin from a conservation genetics perspective.

\section{Conservation actions}

We propose the following actions as urgently needed for the conservation of the Margarita capuchin:

- Hunting of Margarita capuchins must be stopped. The species must be included in the national list of permanently-banned taxa, and it should be upgraded to the Appendix I of CITES.

- To avoid future problems related to disease transmission, hybridisation and resource competition, as a first step, stray monkeys must be captured and measures must be taken to prevent further pet primates from escaping or being intentionally released.

- Pet Margarita capuchins must be managed as a captive population for conservation purposes. To this end, a Monkey Rescue Centre must be established on Isla de Margarita.

- To conduct research on Margarita capuchin conservation genetics, as is already being planned in collaboration with a multi-disciplinary team in Venezuela.

- To stop the primate-pet trade from the Venezuelan mainland and from other countries.

- Since people easily empathise with primates, the Margarita capuchin is an ideal educational flagship to promote the conservation of this capuchin and its mountain habitat.

These actions must be a part of the Margarita capuchin action plan that needs to be developed and implemented in the near future, to focus coming actions on the most pressing issues regarding the survival of this primate.

Acknowledgements. We thank S. García-Rangel for valuable suggestions on the manuscript and essential advice on the GIS analysis and D. Augeri for advice on the GIS analysis. G. Canale, L. Thang Ha, R. Martínez, C. Besançon, A. Pinto, V. Nijman and 3 anonymous reviewers provided valuable com- 
ments that helped to improve the manuscript. Fundacion Vuelta Larga and the Wildlife Research Group provided institutional support. INPARQUES provided long-lasting support, especially A. Marcano and park rangers I. Valera, P. Marcano, M. Gil and D. Gomez for their participation in the pet survey. J. Vásquez, C. Hernandez Marín, V. Zacarías, A. Rodriguez, E. Silva, L. Santana, E. Romagnuolo and D. Romero participated in the surveys as well. M. Pernía assisted in faecal sample tests. R. López provided information about Isla de Cubagua. M. Forti and L. Alio (ARFA) provided bibliographic references. J. Romero and the Perera-Morales, CeballosAballe and Ceballos-Mago families gave logistic support. Financial support was provided by a Captive Care Grant (IPS), Fondo IEA, Primate Action Fund (CI), Denver Zoological Foundation, Rufford Small Grant, IDEA WILD, Cambridge Overseas Trust, Cambridge Philosophical Society, The Anatomy School and Murray Edwards College (formerly New Hall).

\section{LITERATURE CITED}

Allendorf FW, Leary RF, Spruell P, Wenburg JK (2001) The problems with hybrids: setting conservation guidelines. Trends Ecol Evol 16:613-622

Altherr S (2007) Going to pot-the Neotropical bushmeat crisis and its impact on primate populations. Care for the Wild International, Kingsfold, W. Sussex; and Pro Wildlife, Munich. Available at www.prowildlife.de/sites/default/ files/Going \%20to\%20pot_2007.pdf

Baker L (2002) IUCN/SSC Re-introduction Specialist Group: guidelines for nonhuman primate re-introductions. Newsletter of the Re-introduction Specialist Group of IUCN's Species Survival Commission (SSC). No 21

Bodini R, Perez-Hernández R (1987) Distribution of the species and subspecies of cebids in Venezuela. In: Studies in Neotropical mammalogy. Essays in honor of Philip Hershkovitz. Fieldiana Zool New Ser 39:231-244

Bshary R (2001) Diana monkeys, Cercopithecus diana, adjust their anti-predator response behaviour to human hunting strategies. Behav Ecol Sociobiol 50:251-256

Ceballos N (2008) Cebus apella ssp. margaritae. In: IUCN (ed) 2008 IUCN Red List of Threatened Species. www.iucnredlist.org

Ceballos-Mago N (2005) Pet primates on Isla de Margarita, a threat for the wild population of the Margarita capuchin monkey (Cebus apella margaritae). VI Congreso Venezolano de Ecología, Maracaibo

Ceballos-Mago N (in press) Cebus apella margaritae. In: Rowe N (ed) All the world's primates database website. Pogonias Press, Charlestown, RI. Available at www.alltheworldsprimates.com

Chapman CA, Peres C (2001) Primate conservation in the new millennium: the role of scientists. Evol Anthropol 10: 16-33

Chapman CA, Gillespie TR, Goldberg TL (2005) Primates and the ecology of their infectious diseases: How will anthropogenic change affect host-parasite interactions? Evol Anthropol 14:134-144

Chivers DJ (1991) Guidelines for reintroductions: procedures and problems. Symp Zool Soc Lond 62:89-99

> Chomel BB, Belotto A, Meslin F (2007) Wildlife, exotic pets, and emerging zoonoses. Emerg Infect Dis 13:6-11

Colosio AC (2009) Parasitos intestinais em Cebus xanthosternos (Wiedneuwied, 1826) (Primates, Cebidae) na região do Maruim na Reserva Biológica de Una, Bahia, Brasil. MS thesis, Universidade Estadual de Santa Cruz
Coop RL, Holmes PH (1996) Nutrition and parasite interaction. Int J Parasitol 26:951-962

Cordero Rodríguez G, Boher S (1988) Notes on the biology of Cebus nigrivittatus and Alouatta seniculus in Northern Venezuela. Primate Conserv 9:61-67

Corning S (2005) Public health and safety risks involved in the keeping and trade of primates as pets. In: IFAW (ed) Born to be wild - primates are not pets. IFAW, London, p 46-54. Available at www.ifaw.org/Publications/Program_ Publications/Wildlife_Trade/Campaign_Scientific_Publications/assest_upload_file812_49478.pdf

CORPOTUR (Corporación de Turísmo del Estado Nueva Esparta) (2009) Estadísticas turísticas del Estado Nueva Esparta. CORPOTUR. Dirección de Planificación y Desarrollo. Departamento de Estadísticas Turísticas, Porlamar

de Thoisy B, Richard-Hansen C, Peres CA (2009) Impacts of subsistence game hunting on Amazonian primates. In: Garber PA, Estrada A, Bicca-Marques JC, Heymann EW, Strier KB (eds) South American primates: comparative perspectives in the study of behavior, ecology, and conservation. Springer Press, New York, NY, p 389-412

> Dobson AP, Hudson PJ (1992) Regulation and stability of a free-living host-parasite system: Trichostrongylus tenuis in red grouse II. Population models. J Anim Ecol 61: $487-498$

> Duarte-Quiroga A, Estrada A (2003) Primates as pets in Mexico City: an assessment of the species involved, source of origin, and general aspects of treatment. Am J Primatol 61: 53-60

Dudley N (ed) (2008) Guidelines for applying protected area management categories. IUCN, Gland

Duplaix N (2001) Evaluation of the animal and plant trade in the Guayana Shield Eco-Region, preliminary findings. WWF. Available at www.giantotterresearch.com/articles/ Guianas_Trade.pdf

Estrada A (2009) Primate conservation in South America: the human and ecological dimensions of the problem. In: Garber PA, Estrada A, Bicca-Marques JC, Heymann EW, Strier KB (eds) South American primates: comparative perspectives in the study of behavior, ecology, and conservation. Springer Press, New York, NY, p 463-505

Fragaszy D, Visalberghi E, Fedigan L (2004) The complete capuchin. The biology of the genus Cebus. Cambridge University Press, Cambridge

Gillespie TR, Chapman CA (2006) Prediction of parasite infection dynamics in primate metapopulations based on attributes of forest fragmentation. Conserv Biol 20: $441-448$

Glanz WE (1991) Mammalian densities at protected vs. hunted sites in Central Panama. In: Robinson JG, Redford $\mathrm{KH}$ (eds) Neotropical wildlife use and conservation. University of Chicago Press, Chicago, IL, p 163-173

González V (1999) La vegetación del Estado Nueva Esparta. (Mapas de vegetación de las tres islas como anexos; Margarita a escala 1:100.000, Coche y Cubagua a escala 1:25.000. Proyecto DAO-PDVSA-UCV Palmaven, Barcelona

IGVSB (Instituto Geográfico de Venezuela Simón Bolívar) (1997) Proyecto PITSA 1:25.000. IGVSB, Caracas

INE (Instituto Nacional de Estadística) (2001) Estimaciones del Instituto Nacional de Estadística (INE). Servicio de Atención al Usuario (SAU), Porlamar

$>$ Johns AD, Skorupa JP (1987) Responses of rain-forest primates to habitat disturbance: a review. Int J Primatol 8: $157-191$

Kierulff MCM, Santos G, Canale G, Carvalho CE and others (2005) Plano de Manejo para a conservação do macaco- 
prego-do-peito-amarelo, Cebus xanthosternos. Edital FNMA/PROBIO no. 04/2001, IESB, Ilheus

Marquez L, Sanz V (1991) Evaluación de la presencia de Cebus apella margaritae (Hollister, 1914) en la Isla de Margarita. Trabajo Especial de Grado, Universidad Central de Venezuela, Caracas

Martínez R, Moscarella R, Aguilera M, Marquez E (2000) Update on the status of the Margarita Island Capuchin, Cebus apella margaritae. Neotrop Primates 8:34-35

May RM (1988) Conservation and disease. Conserv Biol 2: $28-30$

Moncada R (2007) Evaluación del impacto generado por la fauna silvestre sobre los cultivos en conucos en el P. N. Cerro El Copey, Isla de Margarita (Edo. Nueva Esparta). Trabajo Especial de Grado, Universidad Central de Venezuela, Caracas

Moura AC de A (2007) Stone banging by wild capuchin monkeys: an unusual auditory display. Folia Primatol 78:36-45

Mujica E, Díaz Martin D, Sobrino MC, Novo Torres I, Guex P, Lubo ML (2003) Documento base de la campaña 'Tu casa no es su casa'. Vitalis, Caracas. Available at www.vitalis. net/Tu\%20casa \%20doc\%20base.htm

Myers N, Mittermeier RA, Mittermeier CG, da Fonseca GAB, Kent J (2000) Biodiversity hotspots for conservation priorities. Nature 403:853-858

Nijman V (2005a) Hanging in the balance: an assessment of trade in orang-utans and gibbons on Kalimantan, Indonesia. TRAFFIC Southeast Asia, Petaling Jaya. Available at www.traffic.org/species-reports/traffic_species_ mammals1.pdf

Nijman V (2005b) In full swing: an assessment of trade in orang-utans and gibbons on Java and Bali, Indonesia. TRAFFIC Southeast Asia, Petaling Jaya. Available at www.wwf.org.uk/filelibrary/pdf/fullswing_0605.pdf

Ohl-Schacherer J, Shephard GH, Kaplan H, Peres CA, Levi T, Yu DW (2007) The sustainability of subsistence hunting by Matsigenka native communities in Manu National Park, Peru. Conserv Biol 21:1174-1185

Ottocento R, Marquez L, Bodini R, Cordero R (1989) On the presence of Cebus apella margaritae on Margarita Island, Northeastern Venezuela. Primate Conserv 10:19-21

Phillips KA, Haas ME, Grafton BW, Yrivarren M (2004) Survey of the gastrointestinal parasites of the primate community al Tambopata National Reserve, Peru. J Zool 264: 149-151

Redmond I (2005) The primate pet trade and its impact on biodiversity conservation. In: IFAW (ed) Born to be wildprimates are not pets. IFAW, London, p 10-17. Available at www.ifaw.org/Publications/Program_Publications/ Wildlife_Trade/Campaign_Scientific_Publications/asset_ upload_file812_49478.pdf

Rhymer JM, Simberloff D (1996) Extinction by hybridization and introgression. Annu Rev Ecol Syst 27:83-109

Editorial responsibility: Anna Nekaris,

Oxford, UK
Robinson JG (1996) Hunting wildlife in forest patches: an ephemeral resource. In: Schelhas J, Greenberg R (eds) Forest patches in tropical landscapes. Island Press, Washington, DC, p 111-130

Robinson JG, Bennett EL (eds) (2000) Hunting for sustainability in tropical forest. Columbia University Press, New York, NY

Rodríguez JP (2007) Editorial: Extinción en Margarita. Mem Fund La Salle Cienc Nat 67(167):3-4

Rodríguez JP, Rojas-Suárez F (1999) Libro rojo de la fauna Venezolana, 2nd edn. Provita, Caracas

Rodríguez JP, Rojas-Suárez F (2008) Libro rojo de la fauna Venezolana, 3rd edn. Provita, Caracas

Rylands AB, Mittermeier RA (2009) The diversity of the New World primates (Platyrrhini): an annotated taxonomy. In: Garber PA, Estrada A, Bicca-Marques JC, Heymann EW, Strier KB (eds) South American primates: comparative perspectives in the study of behavior, ecology, and conservation. Springer Press, New York, NY, p 23-54

Rylands AB, Kierulff MCM, Mittermeier RA (2005) Some notes on the taxonomy and distributions of the tufted capuchin monkeys (Cebus, Cebidae) of South America. Lundiana 6(Suppl):97-110

Sanz V (2007) ¿Son las áreas protegidas de la Isla de Margarita suficientes para mantener su biodiversidad? Análisis espacial del estado de conservación de sus vertebrados amenazados. Mem Fund La Salle Cienc Nat 67(167): $111-130$

Sanz V, Marquez L (1994) Conservación del mono capuchino de Margarita (Cebus apella margaritae) en la Isla de Margarita, Venezuela. Neotrop Primates 2:5-8

Scott ME (1988) The impact of infection and disease on animal populations: implications for conservation biology. Conserv Biol 2:40-56

Sugden A (1986) The montane vegetation and flora of Margarita Island, Venezuela. J Arnold Arbor 67:187-232

- Thorne ET, Williams ES (1988) Disease and endangered species: the black-footed ferret as a recent example. Conserv Biol 2:66-74

Trejo-Macías G, Estrada A, Mosqueda Cabrera MA (2007) Survey of helminth parasites in populations of Alouatta palliata mexicana and $A$. pigra in continuous and in fragmented habitat in southern Mexico. Int $\mathrm{J}$ Primatol 28: 931-945

- Turner IM, Corlett RT (1996) The conservation value of small, isolated fragments of lowland tropical rain forest. Trends Ecol Evol 11:330-333

Urbani B (2006) A survey of primate populations in Northeastern Venezuelan Guayana. Primate Conserv 20:47-52

Xena de Enrech N, Escala M, Madriz R (1998) Characterization of the dwarf forest of 'Cerro Copey' (Margarita Island, Venezuela). Bol Mus Munic Funchal (Suppl 5): $147-166$

Submitted: April 16, 2009; Accepted: Apr 30, 2010

Proofs received from author(s): June 14, 2010 